\title{
BYZANTSKÝ POSTOJ K FENOMÉNU „AZYMA“ V DOBĚ VYPUKNUTÍ VÝCHODNÍHO SCHIZMATU
}

MAREK MATĚJEK

\section{Úvod}

$\mathrm{N}_{\mathrm{a}}$

počátku našich úvah ke sporu o azyma je třeba poukázat na jeden důležitý aspekt historie bádání ve věci sporu o otázkách obřadu. Od období novověku se často prosazoval interpretační model postulující zásadní absurditu výtek vyskytujících se v historii náboženství, které se vztahují na cizí obyčeje a zvyky, at už se jedná o výtky liturgické nebo výtky jiného charakteru. O konkrétní obsah sporů tohoto druhu se potom badatelé zajímali zpravidla jen okrajově. Neviděli $v$ tom nic než záminku, na kterou bylo poukázáno, aby byly zastřeny jiné, „skutečné“ zájmy.

Uvedené názory, které od osvícenství dominovaly na vědecké scéně, trpí především tím, že to „podstatné“ a to „nepodstatné“ je v této analýze postulováno jako daná skutečnost. Přitom interprety vůbec nenapadá, že naše představy o tom, co je „podstatné“ a co „nepodstatné“, jsou podmíněny kulturou. Jestliže bude spor o azyma chápán jako „vynález“ patriarchy Michaela Kerullaria, obejdeme touto interpretací důležité otázky: Proč měl zrovna tento „objev“ tak velký úspěch u Byzantinců? Proč považovali byzantští teologové tento fenomén za natolik zásadní a důležitý? Proč si zachoval církevně politický boj o moc mezi patriarchou z Konstantinopole a papežem zrovna takovou, a ne nějakou jinou formu?

Cílem této studie je prověřit argumenty, se kterými vystoupili byzantští teologové proti praxi používání nekvašeného chleba ke slavení eucharistie na Západě v době vypuknutí rozkolu. Jednotlivé argumenty budeme zkoumat v kontextu sjednocovacích tendencí v 11. století, a zejména ve vztahu Byzantské ŕíše k Arménům. 


\section{Historický vývoj}

Od počátku křestanství přinášeli věřící chléb ke slavení eucharistie s sebou z domu. Obvykle se jednalo o kvašený chléb. ${ }^{1}$ Některá společenství na Východě (např. v Alexandrii) však slavila, převzetím židovského zvyku paschy, bohoslužbu s nekvašeným chlebem (azymon; častěji plurál: $a z y m a) .^{2} \mathrm{~V} 5$. až 6 . století se obecně v řecké části církve prosadil kvašený chléb. Důvodem je podle Mahlona H. Smitha silnější zakotvení pavlovské teologie na Východě a její protikladný postoj ve vztahu k židovskému kultu. ${ }^{3}$

Arménská církev slavila liturgii od christianizace řeckou církví v Kaisarei v Kappadokii (poč. 4. století), ale možná až poté, co se v 6. století vyslovila pro monofyzitské učení, s nekvašeným chlebem. ${ }^{4} \mathrm{~V}$ arménské interpretaci byl nekvašený chléb ve vztahu ke starozákonní představě „„̌̌ivotodárné many“ vyjádřením těla Kristova; kvašený chléb byl chápán naproti tomu jako symbol zkažení a zkázy. ${ }^{5}$

Ve Francké říši se pozvolna prosadil přibližně od počátku 9. století nekvašený chléb jako konsekrační materie. Francký teolog Rabanus Maurus, který ve svém díle De institutione clericorum poprvé zmiňuje „panem infermentatum " jako eucharistickou obět, ${ }^{6}$ se vyslovuje pro nekvašený chléb, protože podle Lv 2,11 je zakázáno přinášet Hospodinu kvas jako obět. Také Poslední večeře měla být slavena s nekvašeným chlebem, protože v období paschy nebylo dovoleno vlastnit kvas. ${ }^{7}$ Přitom odkazují $a z y$ $m a$, jak učil apoštol Pavel, na upř́mnost smýšlení. Naopak kvašený chléb znamená „zlo a špatnost“. 8

1 Srov. JUNGMANN, J. A. Missarum Solemnia. 5. vydání. Wien, 1962, s. 41n.

2 Srov. MICHEL, A. Humbert und Kerullarios: Quellen und Studien zum Schisma des XI. Jahrhunderts. Sv. 2. Paderborn, 1930, s. 114-117.

3 Srov. SMITH, M. H. And taking Bread: Cerularius and the Azyme Controversy of 1054. Paris, 1978, s. 161-167. K opozici uvnitř ortodoxní části církve srov. také MICHEL, A. Humbert und Kerullarios. Sv. 2., s. 117.

4 Srov. MICHEL, A. Humbert und Kerullarios. Sv. 2., s. 116; BAYER, A. Die Azymenkontroverse. In BAYER, A. Spaltung der Christenheit: Das sogenannte Morgenländische Schisma von 1054. 2. vydání. Köln: Böhlau, 2004, s. 214.

5 ESBROECK, M. van. Armenien und die Penthektè. Annuarium Historiae Conciliorum 1992, roč. 24 , s. $87-91$.

6 RABANUS MAURUS. De clericorum Institutione (PL 107,318Cn). GEISELMANN, J. R. Die Abendmahlslehre, s. 38. Srov. také KANDLER, K. H. Seit wann werden die Azyma das Brotelement in der Eucharistie im Abendland? Zeitschrift für Kirchengeschichte 1964 , roč. 75 , s. 154.

7 RABANUS MAURUS. De clericorum Institutione (PL 107,319B). Srov. Ex 12,18n. a 13,7.

81 K 5,8. Srov. RABANUS MAURUS. De clericorum Institutione (PL 107,319C). Od patristické doby byl v křestanské symbolice v návaznosti na Mt 16,6 a 12 nekvašený 
Na Západě $a z y m a$ vystřídala do počátku 10. století kvašený chléb jako konsekrační materie. ${ }^{9}$ Tento postup je třeba vnímat $\mathrm{v}$ souvislosti $\mathrm{s}$ narůstajícím významem starozákonních předpisů v karolinské době, ${ }^{10}$ jak to lze doložit u Rabana Maura. Musíme ale vidět také snahu reformního okruhu v 9. století vyjmout svátost oltářní z profánního prostředí i použitím zvláštní materie. Rostoucí úcta ke svátosti oltářní už nepřipouští zvyk, aby věřící přinášel obětní materii s sebou ke slavení liturgie. ${ }^{11}$

$\mathrm{Na}$ byzantské straně se stal ve 40 . letech 11 . století zvyk používání nekvašených chlebů předmětem kritiky a překážkou snah o odstranění rozporů mezi východní a západní částí církve. Ze psaní Michaela Kerullaria vyplývá, že vyloučil Argyra ${ }^{12}$ od přijímání eucharistie během jeho pobytu v Konstantinopoli, protože odmítal uznat kvašený chléb Řeků jako jedinou pravou konsekrační materii. ${ }^{13}$ Rozepři s Argyrem lze datovat ještě před vypuknutí samotného konfliktu, který vedl k roztržce v roce 1054. Došlo k ní v době, kdy Byzantinci ovládli velkou část arménské ř́še (1045) a snažili se disciplínu arménské církve sjednotit s konstantinopolskou. ${ }^{14}$

\section{Azyma v polovině 11. století}

Původ sporu o azyma je tedy spojen s událostmi v letech 1053-1054. Na začátku konfliktu, který vedl k vzájemným exkomunikacím v roce

chléb chápán jako čistý, zatímco kvas jako zkažený. Srov. MICHEL, A. Humbert und Kerullarios. Sv. 2., s. 119n. K tomu také: KANDLER, K. H. Seit wann werden die Azyma, s. 154.

9 BAYER, A. Spaltung der Christenheit, s. 216, pozn. 18, dokládá, že tento přechod souvisel $\mathrm{s}$ přechodem od přijímání na ruku k přijímání do úst. Srov. JUNGMANN, J. A. Missarum Solemnia. Sv. 2., s. 472n. Přijímání do úst se stalo ve Španělsku pravidlem už v roce 839 (koncil v Cordobě), ve Francké říši je vyžaduje poprvé koncil v Rouen (878).

10 Srov. HARTMANN, W. Die karolingische Reform und die Bibel. Annuarium Historiae Conciliorum 1986, roč. 18 , s. 58-74.

11 JUNGMANN, J. A. Missarum Solemnia. Sv. 2., s. 44-46.

12 Argyros byl řecký místodržitel v jižní Itálii. K jeho působení srov. KEMP, F. (ed.). Handbuch der Kirchengeschichte. Sv. 3. Die mittelalterliche Kirche: Vom Frühmittelalter bis zur gregorianischen Reform. Freiburg: Herder, 1985, s. 472.

13 WILL, C. Acta et Scripta quae de controversiis ecclesiae Graecae et Latinae saeculo XI conscripta extant. Leipzig, 1861, s. 177.

14 MICHEL, A. Schisma und Kaiserhof im Jahre 1054. In 1054-1954 : L'église et les églises: Neuf siècles de douloureuse séparation entre l'Orient et l'Occident. Sv. 1. Chevetogne, 1954, s. 376n, se domnívá, že vztah mezi událostmi v Arménii a počátkem konfliktu s římskou částí církve ve věci konsekrační materie nelze prokázat. Další výzkumy tento postoj vyvrací. Srov. RUNCIMAN, S. The Eastern Schism: A Study of the papacy and the Eastern Churches during the XIth and XII $I^{\text {th }}$ centuries. Oxford, 1955, a PETRUCCI, E. Rapporti di Leone IX con Constantinopoli. Studi Medievali 1973, roč. 14, s. 733-831. Zmínění autoři tvrdí, že teprve na základě konfliktu s arménskou církví obracejí patriarchové svoji pozornost rovněž na nekvašený chléb Latinů. 
$1054,{ }^{15}$ stál útok Řeků na zvyk římské církve užívající v eucharistii nekvašený chléb. Koncem roku 1052 nebo na jaře roku 1053 nařídil patriarcha Michael Kerullarios zavř́t latinské kostely a kláštery. ${ }^{16}$ Důvodem byl západní způsob sloužení mše, při které byl používán nekvašený chléb (azyma). Současně (pravděpodobně na jaře roku 1053) zaslal řecký arcibiskup León z Ochridu dopis biskupu Janovi z Trani ${ }^{17} \mathrm{v}$ jižní Itálii. Toto psaní je považováno za první nám známý doklad řecké výhrady proti nekvašenému chlebu. ${ }^{18}$ León vznáší proti jeho adresátovi - a „skrz něho“ proti „všem biskupům Franků“, stejně jako proti samému papeži - řadu výtek, mezi kterými zaujímá první místo zvyk slavení eucharistie s nekvašeným chlebem.

León z Ochridu nazývá nekvašený chléb římské eucharistie termínem ta azyma, staví ho tedy do kontextu židovského kultu, a vytýká Latinům, ${ }^{19}$ že se kvůli nepřístojnému způsobu slavení, dbajícímu azym podle příkladu Mojžíše, řadí do společnosti židů. Pro křestany se nesluší užívání azym podle židovského zvyku: „Azyma neobsahují žádnou památku na Pána a neproklamují jeho smrt, protože pocházejí od Mojžíše a byla předepsána před šestnácti sty lety. V Novém zákoně [...] byla zrušena a byl stanoven jejich konec.“20 León z Ochridu je přesvědčen, že Ježíš neužíval při ustanovení eucharistie židovské azyma, ale artos (chléb). „Chléb“ znamená v argumentaci Leóna z Ochridu výlučně „kvašený chléb“. K hlavní výhradě týkající se azym přidává autor řadu dalších obvinění. Vytýká Latinům také sobotní půst, který ztotožňuje s židovským šabatem, ${ }^{21}$ stejně jako zvyk užívání masa ze zardoušených zvířat jako jeden z pohanských zvyků $^{22}$ a vynechávání Aleluja při bohoslužbách v době postní. ${ }^{23}$ Nejvíce

15 Srov. KAPLAN, M. Le „schisme“ de 1054: Quelques éléments de chronologie. Byzantinoslavica 1995, roč. 56, s. 153-157.

16 Exkomm. I. In WILL, C. Acta et scripta, s. 154a, ř. 3-11.

17 Trani (Turenum) je přístavním městem v Apulii v jižní Itálii na pobřeží Jaderského moře. K jeho největšímu rozkvětu došlo v 11. století v souvislosti se zřízením biskupského sídla.

18 Srov. AWAKUMOV, G. Die Entstehung des Unionsgedankens: Die Lateinische Theologie des Hochmittelalters in der Auseinandersetzung mit dem Ritus der Ostkirche. Berlin: Akademie Verlag, 2002, s. 60-63.

19 Pro označení obyvatel Západu používám termínu „Latinové“, který se běžně vyskytuje v odborné literatuře. Důvodem pro volbu tohoto označení je to, že oficiálním jazykem na Západě byla latina a že ti, kteří přicházeli na Východ, sami sebe nazývali „Latiny“. Srov. ZÁSTĚROVÁ, B. (ed.). Déjiny Byzance. Praha: Academia, 1992, s. 279. WILL, C. Acta et scripta, s. 58b.

21 Tamtéž, s. 58b-59a.

22 Sk 15, 20.29; 21, 25.

23 WILL, C. Acta et scripta, s. 59b. 
se León ve svých výtkách soustředí na $a z y m a .{ }^{24}$ Podle názoru tohoto autora se Latinové stanou dokonalými věřícími $\mathrm{v}$ Krista tím, že přestanou praktikovat chybné zvyky. Bud' se stanou „čistými židy“, nebo „čistými pohany“, nebo „čistými křestany“. Dopis končí výzvou k Latinům, aby přenechali židovské a pohanské zvyky židům a pohanům a tímto „s námi“ (tzn. s Řeky) dosáhli souladu ve víře a tvořili stádo s jediným pastýřem. ${ }^{25}$

Zdá se, že pronásledování latinského způsobu celebrace na byzantském území a s tím spojená antiazymická polemika byla vyjádřením snahy o sjednocení slavení liturgie. ${ }^{26}$ Silné sjednocovací tendence jsou v 11. století charakteristické jak pro Řím, tak i pro Konstantinopol. Sjednocení liturgie na Západě, které vycházelo ještě od Karlovců, dosáhlo právě v 11. století následkem snah reformního papežství svého vrcholu. Jako příklad lze uvést potlačení mozarabských obřadů v roce 1080 na koncilu v Burgosu. ${ }^{27}$

Sjednocovací tendence Konstantinopole byly zaměřeny na jedné straně na Západ, totiž do jižní Itálie. Rivalita řeckého a latinského ritu, ale také navzájem se stř́dající vlny latinizace a helénizace byly už po staletí půdou, na které vyrůstaly konflikty v otázkách obřadu. ${ }^{28}$ Je jasné, že pronásledování zvyku užívání nekvašeného chleba v Konstantinopoli muselo mít nevyhnutelně také dopad na římskou církev na byzantském území v Apulii. ${ }^{29}$ Jedině tak se dá vysvětlit vznik dopisu Leóna z Ochridu

24 AWAKUMOV, G. Der Azymatenstreit: Konflikte und Polemiken um eine Frage der Ritus. In BRUNS, P. - GRESSER, G. Vom Schisma zu den Kreuzzügen 1054-1204. Paderborn: Schöning, 2005, s. 10. WILL, C. Acta et scripta, s. 59b-60a. AWAKUMOV, G. Der Azymatenstreit, s. 10.

27 PINELL, J. Unité et diversité dans la Liturgie Hispanique. In Liturgie de l'église particulière et liturgie de l'église universelle : Conférences Saint-Serge XXII ${ }^{e}$ semaine d'études liturgiques, Paris, 30 juin - 3 juilliet 1975. Rom, 1976, s. 245-260.

28 WIHODA, M. Království slunce: jihoitalští Normané mezi státy, národy a kulturami. Déjiny a soućasnost 2003, roč. 25, č. 6, s. 12-17.

29 RUNCIMAN, S. The Eastern Schism, s. 40n. Jako předpoklad aliance mezi Římem s Byzancí požadoval Kerullarios vzdání se římské teorie o azymech. Zdá se, že Kerullarios vnímal konstantinopolskou a římskou církev jako rovnoprávné. To se také projevilo v jeho požadavcích. V případě, že bude připomínáno jeho jméno v Římě, zajistí, že bude papežovo jméno vyhlášeno „in toto orbe Romano“. To však vyvolalo u kurie dojem, že se Kerullarios cítí být oprávněný řídit celou církev. Opatrněji se k tomuto vyjadřuje SMITH, M. H. And Taking Bread, s. 85, poněvadž není žádný jednoznačný doklad, že by se Kerullarios stavěl na odpor politické alianci, aby zabránil podřízení Byzance Římu. Kerullarios zdůraznil ve svém prvním dopisu Petrovi z Antiochie (WILL, C. Acta et scripta, s. 177), aby nedělal nic z toho, co je mu Římany vyčítáno. Ovšem výtky z 2. ep. ad Cerul. se nezdají být vymyšlené, i když mnohé spočívá v nejednoznačném překladu. K tomu srov. také: DISCHNER, M. Humbert von Silva Candida: Werk und Wirkung des lothringischen Reformmönches. Neuried: Ars Una, 1996, s. 50. 
pro Jana z Trani, pravděpodobně inspirovaného Kerullariem. ${ }^{30}$ Současně s útokem na západní eucharistický zvyk musel sílit odpor řecké církve v jižní Itálii proti její možné latinizaci.

Řecké odmítání $a z y m$ však nebylo od počátku zaměřeno jen proti Latinům, ale také proti Arménům. Tito východní sousedé Byzantinců totiž také používali při slavení eucharistie nekvašený chléb. $V$ roce 1045 byla říše Arménů včleněna do Byzantské říše. Tato skutečnost konfrontovala Řeky s arménskou církví a bezprostředně také s její dogmatickou a liturgickou osobitostí. Vzhledem k vytvořené unii mezi oběma církvemi se Byzantinci snažili o sjednocení zvyků. ${ }^{31}$ Je tedy zřejmé, že kritika používání nekvašených chlebů velmi úzce souvisí s arménskou problematikou. Argumenty pro kvašený a proti nekvašenému chlebu jsou užity jak proti Latinům, tak i proti Arménům a byly v př́slušném kontextu zaměnitelné.

Při zkoumání pramenů vychází najevo, jak důležité místo zaujímalo slavení eucharistie $\mathrm{s}$ nekvašeným chlebem $\mathrm{v}$ byzantské dogmatické polemické literatuře od 11. do 13. století. Problematika azym byla takřka v každém protilatinském spise alespoň zmiňována, ale často také podrobně pojednána. Ve srovnání s ostatními spornými body se v průběhu času měnil význam této otázky. Zatímco azyma $\mathrm{v} 11$. a ve 12 . století nadále ovládala diskuse, od konce 12 . století a ve 13. století se do popředí zájmu dostala problematika filioque. Můžeme vysledovat několik rovin, na kterých se diskutovalo. Ve všedním církevním styku převažovala azyma, zvláště tam, kde Latinové a Řekové žili vedle sebe a ctili stejné církevní struktury, ale oficiální disputace se obracely k jiným sporným otázkám, mezi kterými zaujaly filioque a o něco později otázka papežského primátu nesporně první a druhé místo. Přesto zůstala azyma až do 18. století předmětem polemických úvah. ${ }^{32}$

30 Rozsah skutečného Kerullariova podílu je nejasný: MICHEL, A. Humbert und Kerullarios, s. 282n, přijímá jeho spoluautorství. BECK, H. G. Geschichte der orthodoxen Kirche im byzantinischen Reich. Göttingen, 1980, s. 144, je přesvědčený o promyšleném postupu Kerullaria, který pověřil Leóna z Ochridu vyhotovením spisu proti Latinům, ten měl být rozšířen mezi latinskými biskupy. SMITH, M. And Taking Bread, s. 114, zastupuje názor, že dopis Leóna z Ochridu se týkal otázek ritu církve v rámci byzantského teritoria.

31 Objasnění této problematiky by mohla přinést důkladná analýza byzantských protiarménských textů. Srov. AWAKUMOV, G. Der Azymatenstreit, s. 11. Zkoumání četných protiarménských textů z Byzance, které doposud nejsou editované, by určitě mohlo poskytnout další poznatky o původu sledované polemiky.

$32 \mathrm{Z}$ řeckého jazykového prostoru se téma azym dostalo již v 11. století do východoslovanských oblastí, kde stálo pod byzantským vlivem. Překlady řecké antiazymické literatury se šírily zejména na Kyjevskou Rus. Mnozí řečtí metropolité ve východoslovanských oblastech byli autory takových spisů a leckteré jsou dochovány pouze ve 
Základní argumentační linie pro vyvrácení obřadů s nekvašeným chlebem vytvořili v 11. století autoři, kteří byli spojeni s událostmi roku 1053/ 1054. Arcibiskup León z Ochridu, studijský mnich Nikétas Stéthatos, stejně jako patriarchové Michael Kerullarios z Konstantinopole a Petr III. z Antiochie. Dnes se dá jen velmi těžko odhadnout, který ze jmenovaných autorů přispěl k polemice hlavním dílem. Historik Anton Michel se snažil rozpoznat v obsáhlém spisu, který se nazýval Panoplia a byl připsán Michaelu Kerullariovi, základ polemiky proti Latinům. ${ }^{33}$ Podobnou roli chtěl Michel přisoudit i práci Dialexis od Nikéty Stéthata, ve které viděl programový spis o azymech. ${ }^{34}$ Jak bylo však později dokázáno, Panoplia vznikla až v závěru 13. století. Proto musíme tuto vícevrstevnou kompilaci považovat ne za základ rozvoje protiřímské polemiky, ale za její výsledek. Co se týká spisu Dialexis od Nikéty Stéthata, je názor Michelův sice ne nepravděpodobný, ale $\mathrm{v}$ žádném př́ípadě není pádný. Neexistují totiž žádné zvláštní důvody, aby především Nikétu učinily zodpovědným za antiazymické myšlenkové pochody Byzantinců. Dohromady vykazují antiazymické spisy $\mathrm{v}$ rané fázi 11. století tolik paralel, totiž prrímo doslovných shod, že lze velmi těžko zprostředkovat prvotní vzor a řadit závislé spisy. ${ }^{35}$ Historie antiazymické literatury až do 13. století je tedy nanejvýš spletitá, nehledě na to, že stejná látka byla několikrát přepracována a jeden a týž spis více či méně lehce variován a opakovaně předkládán pod novým názvem.

Texty Byzantinců, které se odvolávají na problém nekvašených chlebů, můžeme $\mathrm{v}$ zásadě zredukovat na dva základní typy. K prvnímu patří ta pojednání, která se výlučně nebo z větší části věnují otázce $a z y m$. Tyto spisy zmiňují někdy také jiné sporné otázky, ale látka z jiných oblastí (sobotní půst, filioque atd.) má pro ně až druhořadý význam. Klasickým příkladem takových spisů je první dokument antiazymické polemiky proti Latinům, dopis Leóna z Ochridu pro Jana z Trani, který Latinům vytýká hlavně obřad s nekvašeným chlebem a také, když podrobně argumentu-

slovanském znění. Bez zřetele na staré slovanské texty je tedy historie antiazymické literatury nemyslitelná. Ruský vědec Michail Čelcov publikoval v roce 1879 dodnes velmi hodnotnou monografii o řecké a slovanské antiazymické problematice: ČELCOV, M. Polemika meždu grekami i latinjanami po voprosu od opresnokach $v$ XI-XII vekach [„Polemika mezi Řeky a Latiny proti azymům v 11. a 12. století“]. St. Petersburg, 1879.

33 Panoplia. In MICHEL, A. Humbert und Kerullarios, s. 207-282.

34 Srov. SMITH, H. Taking Bread, s. 8. MICHEL, A. Humbert und Kerullarios, s. 307, který vychází z toho, že text Dialexis byl zaslán před příchodem legátů do jižní Itálie a Antidialog jako přepracovaná forma Dialexis byl předán legátům. Antidialog je vydán v knize MICHEL, A. Humbert und Kerullarios, s. 322-342.

35 AWAKUMOV, G. Der Azymatenstreit, s. 13. 
je pro odmítnutí azym, zmiňuje některé další omyly Latinů. K druhému typu textů patří seznamy nebo katalogy omylů, ve kterých je výtka proti azymům pouze jedním z bodů a zpravidla nezahrnují žádné speciální pojednání. Za prototyp spisů tohoto druhu můžeme považovat Katalog latinských omylů z prvního dopisu Michaela Kerullaria Petrovi z Antiochie. Dalším vlivným spisem tohoto druhu je anonymní pojednání $O$ Francich a ostatnich Latinech. Také Aitiamata od Konstantina Stilba počítáme ke spisům, kde se objevují azyma a filioque společně s tvrzením, že „Latini jí společně se psy a ochočenými medvědy a myjí se ve vlastní moči“, přičemž autor vůbec neodůvodňuje své odmítání západních mravů. ${ }^{36} \mathrm{I}$ když spisy prvního typu představují důležitější prameny pro porozumění problematice $a z y m$, nesmí být na tyto texty pohlíženo jako na bezvýznamné. Demonstrují, jaké místo a jaký význam zaujímaly otázky azym v celé polemice proti Latinům a jaké závěry z toho vznikly pro styk s nimi. Časem hranice mezi oběma formami traktátů splynula, především potom, když se autoři nebo kompilátoři nespokojili s pouhou zmínkou sporných bodů, ale pustili se do podrobného pojednání. K této „smíšené formě“ patří např́klad dopis kyjevského metropolity Ioanna II. proti papeži Klementovi III., ve kterém vysvětluje velmi podrobně každý z celkem šesti bodů obžaloby proti Latinům, včetně otázky $a z y m$. Nesmíme zapomenout také na vícevrstvé spisy, jako je zmíněná Panoplia, stejně jako příslušné odstavce z teologických a církevněprávních sbírek. Řecké argumentaci proti západnímu zvyku užívání nekvašených chlebů nelze správně porozumět bez ohledu na současnou protiarménskou polemiku. Pro to mluví také objevy Jeana Darrouzèse, že totiž řada byzantských textů proti zvyku nekvašeného chleba, které byly dlouhý čas považovány za protiřímské, jsou ve skutečnosti namířeny proti Arménům. To se vztahuje např. na pojednání o azymech, které bylo Antonem Michelem označeno jako protiřímský spis od Kerullaria, ve skutečnosti však pochází z protiarménského spisu Panoplia dogmatiké. Podobně nakládá i s traktátem Nikéty Stéthata, který editoval pod názvem Contra Armenos et Latinos de fermentato et azymis. Tento vyplývá podle vší pravděpodobnosti z celkové řady pěti protiarménských Nikétových pojednání. Teprve později byla interpolována slova „proti Latinům“ (kata Latinón) do titulu díla a „proti Frankům“ (kata Frangón) na začátek textu. O významu problému azym právě pro byzantskou protiarménskou polemiku svědčí také tř̌i texty z 11. a 12. století, které v roce 1990 vydal Jean Darrouzès.

36 DARROUZÈS, J. Le mémoire de Constantin Stilbès contre les Latins. Revue des études byzantines 1963, roč. 21 , s. $80 \mathrm{n}$. 
V protiazymické polemice Byzantinců můžeme pozorovat několik argumentačních linií.

\subsection{Argument judaizace a ustanovení Poslední večeře}

Většina autorů identifikuje nekvašený chléb užitý při slavení eucharistie s židovskými azymy. Pouhé užití nekvašeného chleba již implikuje účast na židovském kultu. ${ }^{37}$ Každý, kdo užívá nekvašený chléb jako eucharistickou obětní látku, se nachází „ve stínu starozákonního přikázání“ a „zaujímá místo na židovské hostině“. ${ }^{38}$ Výtka „judaizace“ je prvním a asi nejmarkantnějším argumentem v protiazymické polemice.

Sloveso „judaizovat“ (ř. iúdaizein, lat. judaizare), které vyjadřuje žití po židovském způsobu, ${ }^{39}$ se objevuje už v listu Galatským, ${ }^{40}$ kde je Petr kárán, že obrácené pohany nutí následovat starozákonní přikázání, že je chce „judaizovat“. K témuž se vyjadřuje také Ignác z Antiochie: „Je absurdní hlásat Ježíše Krista a současně judaizovat.“41 Pod pojem judaizantes lze shrnout úplně rozdílné skupiny a proudy raného křestanství. V moderní literatuře se občas rozlišuje mezi „židovskými křestany“, tzn. křestany židovského původu, kteří po své konverzi ke křestanské víře nadále dbali starozákonních předpisů, a judaizantes, tzn. pohanskými křestany, kteří alespoň částečně uznávají židovské zákony. Jedním z nejpodrobnějších vyvrácení křestanské judaizace v patristice jsou kázání Jana Chrysostoma, která vznikla v letech 386-387 v Antiochii a která známe pod názvem Adversus Judaeos, ačkoliv ve skutečnosti nejsou zaměřena proti židům, ale proti judaizovaným křestanům. ${ }^{42}$ Ve sporu proti judaizantes nejde o otázky věroučné, ale o kultické zvyky a obřady, které však v některých případech hrály jak pro křestany, tak i pro židy a pohany mnohem důležitější roli než učení. Vymezení a odsouzení židovských obřadů se objevuje obzvláště tam, kde na úzkém prostoru společně žily větší společnosti křest́anů a židů.

Proces vymezení vůči židovské kultické praxi se projevil i v křestanském zákonodárství. K nejznámějším zákonům proti judaizantes patří

37 LEÓN Z OCHRIDU. Epistolé deutera peri tón azymón. In PITRA, J. B. (ed.). Analecta sacra et classica spicilegio solesmensi patata. 6. sv. Paris, 1891, s. 756.

38 NIKÉTAS STÉTHATOS. Dialexis pros Frangús égún Latinús. In MICHEL, A. Humbert und Kerullarios, s. 321.

39 Srov. SOUČEK, J. B. Řecko-český slovnik k Novému zákonu, s. 127.

40 Ga 2,11-14.

41 Srov. IGNATIUS ANTIOCHENSIS. Ad Magnesios (PG 5,771): „Absurdum est Jesum Christum sonare lingua, et habere in mente abolitum Judaismum..."

42 IOHANNES CHRYSOSTOMUS. Adversus Judaeos (PG 48,843-944). 
tzv. Apoštolské kánony, které vznikly pravděpodobně na konci 4. století v Antiochii. Tvoří dodatek ke Constitutiones Apostolorum. Dokument, který byl vydán jako dílo $\mathrm{z}$ doby apoštolů, byl v pozdèjší době velmi vlivný. Na Západě bylo uznáno sice jen prvních 50 z celkového počtu 85 kánonů, ale v Byzanci potvrdila Trullská synoda v roce 691 autoritu všech 85 apoštolských kánonů. Kánon 7 hrozí jáhnům, kněžím a biskupům suspendací, pokud by paschu slavili „před jarním dnem a jarní rovnodenností společně se židy“. ${ }^{43}$ Kánon 65 podrobuje klerika exkomunikaci, pokud by šel „na modlitbu do židovské synagogy“. ${ }^{44}$ Kánon 71 exkomunikuje křestana, pokud by „přinesl olej do pohanské modlitebny nebo do židovské synagogy nebo na jejich svátek zapálil svícen“. ${ }^{45}$ Pro nás je však obzvláště zajímavý kánon 70: „Jestliže se nějaký biskup nebo jiný klerik postí společně s židy nebo společně s nimi slaví jejich svátky nebo přijímá na jejich slavnostech dary, jako např́klad azyma nebo něco podobného, bude suspendován. Jestliže se tohoto dopustí laik, bude exkomunikován.“46

Podle toho by měl být každý křestan, který přijímá židovská azyma, potrestán. ${ }^{47}$ Byzantští polemikové transferují otázku o povaze eucharistického chleba anachronicky do kontextu polemiky proti judaizaci v prvních stoletích po Kristu. Polemika se neomezuje jen na otázku chleba, ale sleduje i jiné židovské zvyky a obřady jako oslavu šabatu, obřízku atd. Nikétas Stéthatos například vznáší na adresu Latinů otázku: „Když už chcete jíst azyma, proč se rovnou nenecháte také obřezat?“48 Takto do krajnosti hnané otázky byly pro antiazymickou literaturu obvyklé. Proti západnímu zvyku nekvašeného chleba bylo často argumentováno kánonem 11 z koncilu in trullo, který vyslovil zákaz jíst azyma na židovské slavnosti nekvašeného chleba. Přitom nehrálo podle názoru řeckých autorů rozhodující roli to, jestli se Latinové židovské slavnosti nekvašeného chleba účastnili, nebo ne: „Když řeknete, že nepřijímáte azyma od židů, ale děláte je doma,

43 METZGER, M. (ed.). Constitutiones Apostolorum. Sv. 3. Paris, 1987, s. 276.

44 Tamtéž, s. 298.

45 Tamtéž, s. 300.

46 Tamtéž, s. 300. K tomu srov. AWAKUMOV, G. Der Azymatenstreit, s. 17.

47 Jako pramen pro tento kánon sloužil očividně kánon 38 synody v Laodikeji, kde bylo přesně stanoveno, že „se nesluší přijímat od židů azyma nebo se účastnit jejich bezbožností. AWAKUMOV, G. Der Azymatenstreit, s. 17, k tomu dodává: „Schließlich wiederholt bereits im 7. Jahrhundert das Konzil in Trullo in Kanon 11. erneut das Verbot, auf irgendeine Weise mit den Juden Umgang zu pflegen und deren Azymen zu essen."

48 NIKÉTAS STÉTHATOS. Kata Armenión kai Latinón peri enzymón kai azymón (lat. Contra Armenos et Latinos de fermentato et azymis). In HERGENRÖTHER, J. (ed.). Monumenta Graeca ad Photium ejusque historiam pertinentia. Regensburg, 1869, s. 144. 
co to má být? Jestliže přijímáte azyma od židů, nebo je děláte doma, jsou to stejně azyma, a proto dostanete ještě větší trest. Ten, který dělá a jí nekvašený chléb, i když ho nepřijímá od židů, ale v této věci přejímá jejich zvyk, myslí jako žid a proviňuje se proti zákonu, podobně, jako když se někdo nechá obřezat, i když není obřezán od židů, nicméně smýšlí jako žid.“49

Podezření z „judaizace“ nabídlo byzantským autorům př́ležitost reflektovat poměr Nového zákona ke Starému, přičemž bylo především zdůrazněno, že starozákonní kultické předpisy byly zrušeny $\mathbf{v}$ Novém zákoně. Tak představují druhý a třetí dopis Leóna z Ochridu o azymech v podstatě malé traktáty o vztahu obou Zákonů. Obsáhlé úvahy na toto téma můžeme najít také v jiných antiazymických spisech. Výpovědi bazírují na pavlovském a klasicky patristickém duševním majetku a neobsahují teologicky viděno nic nového. Je užito obvyklých křestanských vysvětlení starozákonního kultu: rozlišování mezi „„ělesným“ a „duchovním“ chápáním kultovních předpisů, konfrontace kněžství Árona ${ }^{50}$ a Melchisedecha ${ }^{51}$ nebo kněžství „nových národů křestanů“ nebo národů pohanů a židů. Nové je v tomto kontextu použití těchto protikladů k pochopení vztahů mezi křestanskými církvemi.

Zvláštnímu zájmu se těší teorie Leóna z Perejaslavle, který se pokouší vysvětlit, proč Latinové propadli judaizaci. Vidí souvislost mezi tímto rozvojem a příkazem císaře Hérakleia (610-641), který nařídil nucený křest židů v západní části římské říše. León cituje dopis Maxima Homologéta, který projevil obavu, že př́kaz císaře eparchovi na Západě, aby pod pohrůžkou smrti dal pokřtít všechny židy, může křestanům přinést jen „zkázu“: „Obávám se, že se židé nechají pokřtít jen ze strachu a že jakmile se budou moci volně stýkat $\mathrm{s}$ národem věřících v Krista, zničí ho. "52 León z Perejaslavle píše v této souvislosti: „Tehdy světec řekl toto proroctví, ale později se tato slova vyplnila, a vidíte, co se dnes před vámi děje. Časem se mnozí židé stanou kleriky, kněžími a biskupy. Nebudou mít sice moc veřejně obnovit židovství, ale s malými př́davky dosáhnou lstivě toho samého. “53

Jeden z dokladů spatřuje León $\mathrm{z}$ Perejaslavle právě v nekvašeném chlebu Latinů. Paralelně k výtce judaizace byly proti Latinům namíře-

49 NIKÉTAS STÉTHATOS. Dialexis, s. 334.

50 K Áronovi: Ex 28,1; Nu 26,59.

51 Srov. Gn 14,18.

52 Cit. z: AWAKUMOV, G. Der Azymatenstreit, s. 18.

53 Tamtéž, s. 18n. 
ny i výtky „helénizace“, tj. zachovávání pohanských zvyků. Výtka „judaizace“ a výtka „helénizace“ stojí v antiazymických traktátech často vedle sebe. V mnoha spisech je Latinům vytýkána i „armenizace“. Arméni jsou totiž také označováni jako „židovsky myslící“ - z téhož důvodu, protože slaví eucharistii s azymy.

V této souvislosti se dá říci, že pro převládající většinu byzantských teologů je výtka judaizace rozhodujícím argumentem proti zvyku používání nekvašeného chleba $v$ eucharistii.

Další argumentem je tvrzení Řeků, že Ježíš slavil Poslední večeři ne s nekvašeným, ale $s$ kvašeným chlebem. Většina byzantských autorů je toho názoru, že židovská pascha „padla“ v den ukřižování Ježíše. Viděli jako svůj hlavní úkol argumentovat ve prospěch toho, že Ježíš př̀i ustanovení eucharistie, tedy při Poslední večeři, $v$ každém případě použil kvašený chléb. Ježíšem vykonaný obřad byl ustanovením principiálně nového mystéria, a ne oslavou židovské paschy, proto použil kvašený chléb. Kladou důraz na to, že Ježíš v den, kdy slavil Poslední večeři, neoslavoval židovské vyjití z egyptského otroctví, nýbrž ustanovil nové křestanské mystérium eucharistie. Toto mystérium nechtěl ustanovit se starou, zákonem předepsanou látkou - s azymy, proto k tomu použil kvašený chléb. Tak León z Ochridu píše: „Kristus se nechal obřezat, aby nebyl považován za bezbožného, a oslavil nejdříve starozákonní paschu. Tehdy ve čtvrtek pašijového týdne však přestal slavit onu starozákonní paschu a ustanovil novou, naši paschu. “54 Také jiní autoři se vyslovili ve smyslu, že Ježíš oslavil mystickým způsobem „vlastní paschu“, oslavil „tajemství Boží mystagogie“. Nikétas Stéthatos shrnuje své zkoumání o Poslední večeři následovně: „Vy [Latinové a Arméni] máte vědět, že jste nemohli převzít požívání a obět azym od Krista nebo od apoštolů, protože ani Kristus, náš Bủh, v čas svého utrpení nejedl azyma, která tehdy ještě nebyla rozšířena mezi židy, ani vám apoštolové nemohli předat to, co sami nemohli převzít.“"55

\subsection{Argument podstaty chleba}

Tento argument vychází z fyzické povahy chleba, který se teprve díky kynutému těstu stává chlebem, tedy nutně poukazuje na kynuté těsto. „Pán nevzal azyma, s díky je nelámal a nedával apoštolům, nýbrž chléb, jak to dosvědčují čtyři evangelisté a svatý apoštol Pavel.“56 Slovo chléb (artos), které se používá v novozákonních textech, odkazuje na názor by-

54 LEÓN Z OCHRIDU. Epistolé, s. 56a.

55 NIKÉTAS STÉTHATOS. Kata Armenión kai Latinón, 7, s. 146.

56 Tamtéž, s. 139. 
zantských polemiků, že Ježíš použil ne nekvašený, ale kvašený chléb. Řečtí autoři vztahují etymologii slova chléb (artos) na slovo vyzvednout (airó) a dokonalý (artios), ve smyslu, že tato obě slova charakterizují těsto, ze kterého je připravován kvašený chléb. Patří tedy k substanci, k podstatě chleba, k jeho kvašení. Nekvašený chléb tudíž není žádný chléb.

V řecké teologii v patristickém a středověkém období se často používá ve vztahu k eucharistickým podstatám pojem antitypa, ${ }^{57}$ který je klíčovým pojmem pro porozumění symbolické argumentační linii. Argument vychází z toho, že mezi fyzickou povahou chleba, který se užívá při eucharistii, a tělem Krista musí být určitá shoda a symbolická podobnost: chléb jako fyzická substance reprezentuje tělo Krista, a je tedy jeho antitypon. ${ }^{58}$ Byzantští autoři kladli důraz na to, že konečně kvašený chléb může vykonávat funkci symbolické reprezentace. Nekvašený chléb se k tomu nehodí, jeho fyzická povaha odporuje této funkci.

Proč je podle řeckých autorů kvašený chléb jako symbol těla Kristova vhodnější než nekvašený? Již jsme zmínili, že nekvašenému chlebu, ale také kynutému těstu byly v Novém zákoně připisovány určité symbolické kvality. Byzantští polemikové 11. století přidali k této staré interpretaci kynutého těsta ještě jednu vlastnost. Kynuté těsto „oživuje“ a „ohřívá těsto jistou živoucí silou“, takže chléb, který takto vzniká, je „oduševnělý“. Naproti tomu, „jak přirozenost věcí sama ukazuje“, je nekvašený chléb „bez duše“: „Neexistuje žádná živoucí síla v azymech, protože jsou mrtvá.“59 Kořeny těchto názorů se daly najít u středověkých fyziologů, konkrétní podklady k tomu dodal Albert Veliký, který odkazoval na zoologický spis Aristotela jako na možný pramen byzantských názorů. Albert vidí v Aristotelově díle De animalibus XVII možný zdroj názoru Řeků a tvrdí, že to samé četl sám v řeckých knihách. ${ }^{60}$

Jen eucharistie s kvašeným chlebem garantuje symbolickou shodu fyzického elementu s „tělem Páně“. Protože kvašený chléb je sám „oduševnèlý“, je vhodný k tomu, aby se stal eucharistií. Obráceně to znamená, že kdo pro slavení eucharistie používá nekvašený chléb, tzn. chléb „bez duše“, nemůže na základě této argumentace dosáhnout Kristova zpřítomnění.

Z tohoto myšlenkového pochodu vycházely dalekosáhlé závěry vztahující se k pravověrnosti Latinů. Pokud Latinové slaví eucharistii s azymy,

57 Antitypon = to, co odpovídá vzoru. Srov. SOUČEK, J. B. Řecko-český slovník, s. 36.

58 Srov. 1 P 3,21. V tomto smyslu často argumentuje Nikétas Stéthatos. K tomu: AWAKUMOV, G. Der Azymatenstreit, s. 21.

59 NIKÉTAS STÉTHATOS. Kata Armenión kai Latinón, 7, s. 142.

60 AWAKUMOV, G. Der Azymatenstreit, s. 22. 
popírají, že Ježí̌ Kristus přijal tělo, které bylo obdařeno lidskou duší. León z Perejaslavle vytýká Latinům ze stejného důvodu nestorianismus. Další autoři je obviňují z herezí Maního, Valentina, Apollinaria, Pavla ze Samosaty, Eutycha, Dioskora, Sergia a Pyrrha. Je tedy zřejmé, že pro byzantské autory nebyl zvyk užívání azym podružný, ale naopak se dotýkal samé podstaty křestanského vyznání, tedy tzv. „hypostatické unie“v eucharistii.

\section{Postoje byzantských autorů vrcholného středověku}

V textech byzantských autorů se $\mathrm{v}$ námi sledovaném období nejčastěji vyskytovala obvinění z hereze, která sahala od „judaizace“ až k „apollinarianismu“. Celá řada ostrých obvinění dává podnět $k$ domněnce, že byla zpochybněna také platnost svátosti udílené s nekvašeným chlebem. Podle Nikéty Stéthata přijímají Latinové a Arméni, když slaví eucharistii s nekvašeným chlebem, „mrtvé tělo, a ne tělo živého Krista“ “ ${ }^{61}$ Patriarcha Germanos z Konstantinopole důrazně popírá konsekraci u Latinů: „Jestliže ti nějaký Latin říká, že konsekrační azyma se stanou tělem Kristovým, odpověz mu: Jak může být konsekrováno něco, co je Bohem nenáviděné a jako nedokonalé zavrhnuto?“62 Latinská zpráva čtyř žebravých mnichů o disputaci s Řeky pod vedením patriarchy Germana II. v Nikaji a Nymfaiu v roce 1234 uvádí, že řecká strana se $\mathrm{v}$ tomto smyslu jednoznačně vyjádřila, že obřad s azymy není možný. Všichni patriarchové, kteří byli prrítomní na tomto koncilu, potvrzují toto mínění slovy: „Toto je naše víra, tak věříme.“ Autoři 13. století, ke kterým patří také Germanos, jsou ve svých zavrženích azym stále netolerantnější.

I když je možné pozorovat u jednotlivých autorů rozdíly v intenzitě jejich odmítání, byla dominující tendence byzantské polemiky jednoznačně intolerantní. Ve velkém množství autorů, kteří psali o azymech, se nacházejí čtyři osoby, u kterých se setkáváme s tolerantnějšími názory: patriarcha Petros III. z Antiochie, arcibiskup Theofylaktos z Ochridu, Theórianos Filosofos a Démétrios Chómaténos. Z nich se jen Theórianos a Démétrios důsledně a jednoznačně shovívavě stavěli k celebraci s azymy a důrazně nebo implicitně odmítali všechny čtyři zde představené argumentační linie. Dva druzí autoři byli sice o něco tolerantnější než ostatní polemikové, ale oba dva nepochybovali o svém názoru, že azyma nesmí být obětní látkou.

61 NIKÉTAS STÉTHATOS. Kata Armenión kai Latinón, 13, s. 152.

62 GERMANOS Z KONSTANTINOPOLE. Fragment gegen Azymen. In DONDAILE, A. Contra Graecos: Premiers écrits polémiques des dominicains d'Orient. Archivum Fratrum Praedicatorum 1951, roč. 21, s. 430. 
Theórianos ve 12. a Démétrios Chómaténos ve 13. století vypadají jako jediní byzantští autoři, kteří se ve věci azym jasně odlišují od všech ostatních autorů. Theórianos uznává rovnoprávnost obou zvyků. Proti tzv. „fyzickému“ argumentu nepochopitelně zjištuje, že oba druhy chleba jsou vhodné k tomu, aby byly eucharistickou obětní látkou: „Svatý chléb je, předtím než je konsekrován, at' nekvašený nebo kvašený, stejným způsobem chléb a je nazýván božím slovem chléb. Po konsekraci už to není nekvašený nebo kvašený chléb, ale tělo Pána, a ne jedno proti druhému. Slovo chléb označuje druh a stejným způsobem vypovídá o kvašeném a nekvašeném. Ty oba jsou pouze typem. ${ }^{\text {“63 }}$

Kromě toho napomíná Theorianos adresáty svého dopisu, řecké mnichy, aby považovali Latiny za bratry stejné víry: „Milujte Latiny jako své bratry, jsou pravověrní a děti katolické a apoštolské církve jako my. Otázky o azymech - jestliže se vủbec nějaké mají dávat - se v žádném případě nedotýkají víry. Vše je dobré, když to činíme k velebení Boha. Bud' zvyk Latinů, nebo náš zná věci, které se neproviňují proti přiměřenosti a správnosti, ale jsou tak Bohem stanoveny a posvěceny. Pro ty, kteří mají porozumění, je tedy vše správné, pro ty, kteří nedokážou porozumět, ale skandál a pohoršení.“64

\section{Závěr}

Z provedeného bádání vyplývá, že antiazymická polemika neměla celkově systematický a $\mathrm{v}$ žádném př́ípadě přísně racionální charakter. Kritika ukazuje zpravidla jen „tendenci“ a odkazuje nás na „smýšlení. Celá antiazymická polemika je $\mathrm{v}$ první řadě kladením otázek po eucharistickém používání nekvašeného chleba.

Argumenty byzantských autorů je třeba vnímat v kontextu sjednocovacích tendencí v 11 . století. Nebyly zaměřené výlučně proti představitelům západní části církve, ale také proti Arménům. Mezi kritiky vynikali arcibiskup León z Ochridu, mnich Nikétas Stéthatos, ale také patriarcha Michael Kerullarios z Konstantinopole a Petr III. z Antiochie. Nejpádnějším argumentem proti používání nekvašených chlebů bylo tvrzení, že tím dochází k podílu na židovském kultu. Často se opakoval také názor, že nekvašený chléb není pravým chlebem, a nemůže být proto konsekrační materií. Přesto nacházíme na byzantské straně i umírněné teology, kteří uznávali rovnoprávnost obou zvyků.

63 Cit. dle: AWAKUMOV, G. Der Azymatenstreit, s. 25.

64 Tamtéž, s. 25. 
Závěrem lze poznamenat, že zkoumání diskuze o obřadech a zvycích může objasnit kulturní konflikty mezi východní a západní církví. Mezi spornými otázkami, které rozdělovaly Východ a Západ, zaujímaly a zaujímají otázky obřadu mnohem důležitější místo, než se obvykle ve výzkumu připouští. Nejen tyto sporné body, mezi nimiž představuje problematika azym jedno z podstatných témat, charakterizují vlastní kulturní a teologicko-historický typ, ale pozorovatelé mohou také odhalit všeobecnou „rituální“ dimenzi v tisícileté historii napjatých poměrů mezi východní a západní církví.

Spory mezi východní a západní církví, které jsou pro dnešního člověka často těžko akceptovatelné a které jsou zakořeněné $v$ dějinách, by byly lépe pochopitelné, jestliže bychom je byli schopni uchopit jako aspekt rituálu. S pomocí tohoto přístupu se stane také na Západě „ritualismus“ východní církve pro nás srozumitelnějším.

Marek Matějek (1977), Katedra pastorálnich oborů a právnich věd KTF UK

\begin{abstract}
MAREK MATĚJEK

The Byzantine Approach to the "Azyma" at the Beginning of the Eastern Schism
\end{abstract}

The aim of this case study is to verify the arguments that were applied by Greek theologians against the practice of using unfermented bread for Eucharist celebrations in the West at the beginning of the schism. The research has shown that each argument is to be considered in the context of integrating trends in the $11^{\text {th }}$ century. Therefore, they were not solely directed against the representatives of the Western part of the Church, but also against the Armenians. Among the critics the archbishop Leon from Ohrid, the monk Niketas Stethatos, but also the patriarch Michael Kerullarios from Constantinople and Peter III from Antiochia were the most prominent ones. The most cogent argument against the usage of unfermented bread was the accusation of Judaism and the allegation that unfermented bread is not the real bread and cannot be thus used as a consecrating substance. Nevertheless, on the Byzantine side there were also moderate theologians who acknowledged equality of both manners.

\title{
Key words
}

Byzantium, unfermented bread, liturgy, schism 